\title{
СКРИНІНГ ФІБРИЛЯЦІЇ ПЕРЕДСЕРДЬ, ЇЇ ПРИЧИННІ МЕХАНІЗМИ, АНАЛІЗ ЕТІОЛОГІЧНИХ ЧИННИКІВ І ТРИГЕРІВ У ХВОРИХ НА АРТЕРІАЛЬНУ ГІПЕРТЕНЗІЮ ТА ЦУКРОВИЙ ДІАБЕТ 2 ТИПУ (ОГЛЯД ЛІТЕРАТУРИ ТА ВЛАСНІ СПОСТЕРЕЖЕННЯ)
}

\section{Скринінг фібриляції передсердь, її причинні механізми, аналіз етіологічних чинників і тригерів у хворих на артеріальну гіпертензію та цукровий діабет 2 типу (огляд літератури та власні спостереження) \\ Ю. В. Гончарук, М. В. Гребеник \\ Тернопільський національний медичний університет імені І. Я. Горбачевського МОЗ України}

Резюме. Підвищення артеріального тиску (AT) реєструють майже у 25 \% населення світу. Поширеність артеріальної гіпертензії (АГ) збільшується з віком і у 50-60 років складає $70 \%$. Також за даними ВООЗ, у 171 млн (8,5\%) населення світу наявний підтверджений цукровий діабет (ЦД), а через 20 років прогнозують збільшення його частки до 366 млн, тобто на $114 \%$. ЦД у хворих на АГ буває у 2-3 рази частіше, ніж в осіб без АГ. Майже 50 \% 50-річних пацієнтів із вперше виявленим ЦД також мають і АГ. Дослідження ВООЗ показали, що при ЦД тривалість життя зменшується на 10-30\%, а смертність підвищується в 2-3 рази. Причому 7580 \% хворих на ЦД помирає від ураження серцево-судинної системи. Одним із найбільш частих ускладнень АГ ЦД є розвиток фрібриляції передсердь (ФП).

Мета дослідження - проаналізувати стан вивчення та наукові досягнення, що стосуються прогнозування та перебігу ФП в умовах коморбідних АГ і ЦД, та провести клініко-статистичні зіставлення з даними власних спостережень.

Матеріали і методи. Проаналізовано наукові джерела за 2009-2018 рр., що стосуються АГ, ЦД і порушень серцевого ритму. Паралельно обстежено 186 пацієнтів із АГ та ЦД віком від 20 до 74 років.

Результати. За низкою характеристик результати, які ми отримали, корелювали з літературними даними. Однак не усі епідеміологічні дослідження дали однозначну позитивну відповідь на питання про незалежність причинно-наслідкового характеру взаємозв'язку між АГ, ЦД і виникненням чи погіршенням прогнозу ФП. Ймовірно, різниця цих досліджень могла бути пов'язана з різною методологією, зокрема різними характеристиками пароксизмів ФП, тривалістю ЦД, ступенем глікемічного контролю та ін.

Висновки. Отже, ФП є частим клінічним синдромом, особливо в умовах коморбідності. На даний час (СЮ. В. Гончарук, М. В. Гребеник, 2020
Atrial fibrillation screening, its causal mechanisms, analysis of etiological factors and triggers in patients with hypertension and type 2 diabetes mellitus (literature review and own observations)

Yu. V. Honcharuk, M. V. Hrebenyk

I. Horbachevsky Ternopil National Medical University e-mail: honcharuk@tdmu.edu.ua

Summary: Increases in blood pressure are registered in almost $25 \%$ of the world's population. The prevalence of arterial hypertension (AH) increases significantly with age and in 50-60 years is $70 \%$. According to the WHO, 171 million (8.5 \%) of the world's adult population have confirmed diabetes, and in 20 years the proportion of its detection is predicted to increase to 366 million or $114 \%$. $D M$ in patients with hypertension is 2-3 times more common than in people without hypertension. One of the most common complications of hypertension and diabetes is atrial fibrillation.

The aim of the study - to analyze the state of study and scientific achievements related to the prediction and course of AF in comorbid hypertension and diabetes and to conduct clinical and statistical comparisons with the data of their own observations.

Materials and Methods. Scientific sources for 20092018 were analyzed. 186 patients with hypertension and diabetes aged 20 to 74 years were examined.

Results. According to the characteristics range of our results coincided with the literature. But, not all epidemiological studies gave a clear positive answer to the question of the independence of the causal nature of the relationship between hypertension, diabetes and the occurrence or deterioration of the prognosis of AF. Probably, the difference could be related to different research methodologies, including different characteristics of AF paroxysms, duration of diabetes, degree of glycemic control, etc.

Conclusions. Thus AF is a fairly common clinical syndrome, especially in conditions of comorbidity. Currently, the prevalence of hypertension in combination with diabetes is significant and is undoubtedly associated with the occurrence of AF. In this case, they together have a direct impact on the course of the underlying pathology and the course of the arrhythmic syndrome. Therefore, further 
розповсюдження АГ в поєднанні з ЦД є значно та беззаперечно пов'язане із розвитком ФП. При цьому вони разом мають безпосередній вплив як на перебіг основної патології, так і на перебіг аритмічного синдрому. Тому особливої актуальності набуває подальше ретельне вивчення проблеми виникнення і розвитку ФП в умовах коморбідних АГ і ЦД.

Ключові слова: артеріальна гіпертензія; цукровий діабет; фрібриляція передсердь.

\section{ВСТУП}

Підвищення артеріального тиску (АТ) реєструють майже у $25 \%$ населення світу. Поширеність артеріальної гіпертензії (АГ) значно збільшується 3 віком і у 50-60 років складає 70 \% [5]. Розповсюдження цукрового діабету (ЦД) - значне. За даними Всесвітньої організації охорони здоров'я (ВОО3), у 171 млн (8,5 \%) дорослого населення світу наявний підтверджений ЦД, а через 20 років прогнозують збільшення частки його виявлення до 366 млн, тобто на 114 \% [7]. Згідно з прогнозами ВОО3, ЦД буде займати 7 місце серед причин смертності населення вже до 2030 р. ЦД у хворих на АГ зустрічається у 2-3 рази частіше, ніж в осіб без АГ. Майже 50 \% 50-річних пацієнтів із вперше виявленим ЦД також мають і АГ [5]. Також результати досліджень ВООЗ показали, що при ЦД тривалість життя зменшується на 10-30 \%, а смертність підвищується в 2-3 рази. Причому 75-80 \% хворих на ЦД помирають саме від ураження серцево-судинної системи [14]. Одним із найбільш частих ускладнень АГ і ЦД є розвиток аритмій, зокрема фрібриляції передсердь (ФП).

Метою дослідження було проаналізувати стан вивчення та наукові досягнення, що стосуються прогнозування та перебігу ФП в умовах коморбідних АГ і ЦД, та провести клініко-статистичні зіставлення з даними власних спостережень.

\section{МАТЕРІАЛИ I МЕТОДИ}

Проведено детальний аналіз наукових джерел за 2009-2018 рр.: google scholar, library.gov, pubmed, escardio.org, webcardio.org, ukrmed.org, elibrary та ін., які стосуються АГ, ЦД і порушень серцевого ритму.

Паралельно обстежено упродовж 2018-2020 pp. 186 пацієнтів із АГ та ЦД віком від 20 до 74 років (середній - 59,16士0,77). Діагноз ФП встановлювали на підставі документально зареєстрованих епізодів цієї аритмії за даними електрокардіографрії (ЕКГ) або холтерівського моніторування ЕКГ (XM ЕКГ) із урахуванням рекомендацій EHRA (2018). Форма ФП визначалась згідно з Національними рекомендаціями 3 діагностики та лікування ФП. Визначення стадії АГ та типу ЦД проводили careful study of the problem of the origin and development of $A F$ in comorbid hypertension and diabetes becomes especially relevant.

Key words: arterial hypertension; diabetes mellitus; atrial fibrillation.

згідно із загальноприйнятними рекомендаціями Європейського товариства кардіологів (2018) та Європейської асоціації з вивчення діабету (2019).

Структурований збір даних для дослідження (клінічних, лабораторних та клініко-інструментальних) здійснювали в електронних таблицях Microsoft Excel, дані обробляли методами статистичного аналізу за допомогою програми SPSS v.21. Перевірку статистичних гіпотез проводили при критичному рівні значущості p=0,05, тобто відмінність вважалося статистично достовірною, якщо $\mathrm{p}<0,05$.

\section{РЕЗУЛЬТАТИ Й ОБГОВОРЕННЯ}

Згідно зі статистичними звітами, щорічно діагностуються 120 000-215 000 нових випадків ФП. При цьому передбачуваний ризик розвитку ФП упродовж життя в загальній популяції становить 22-26\% [8]. Ймовірність розвитку ФП за життя приблизно в 1,5 раза більша в чоловіків, ніж у жінок [3]. Згідно з дослідженнями EACTS (2016), що провели серед пацієнтів із ФП, виявлено, що чоловіки з даною патологією були в середньому на 5 років молодші за жінок. Частота та поширеність ФП з урахуванням віку нижча у жінок, тоді як ризик смерті у них із ФП вищий.

У когорті обстежених пацієнтів з АГ і ЦД ФП виявлено у 149 (80,1\%). Серед них ідіопатична ФП (10\%), ФП в поєднанні з АГ $(62,4 \%)$ та ФП з коморбідними АГ та ЦД 2 типу (27,6 \%).

У цілому серед обстежених із даною коморбідністю підтверджено переважання осіб чоловічої статі $(61,7 \%)$ ( $p=0,0001)$. При цьому середній вік чоловіків із ФП був $(59,5 \pm 0,9)$ року, тоді як жінок $(63,5 \pm 1,0)$ року, тобто чоловіки були в середньому на 4 роки молодшими ( $p=0,004)$.

Ризик інфаркту міокарда та інсульту за системою Procam Weibull виявився найвищим в групі 3 ФП, АГ та ЦД і становив в середньому 17,3 \% проти групи ідіопатичної ФП, де цей ризик був дещо нижчим - 10,9 \%.

10-річний ризик розвитку ЦД за шкалою DRS y когорті обстежених хворих у середньому становив 7 балів, що оцінювався як відносно низький.

Доведено, що у хворих, які мають надмірну масу тіла або ЦД, пароксизми ФП виникають ра-
ISSN 2706-6282(print)

ISSN 2706-6290(online)
Вісник медичних і біологічних досліджень Bulletin of Medical and Biological Research
$4(6), 2020$ 
ніше - у віці від 40 до 50 років [6]. Ми виявили, що у хворих, які відрізнялись надмірною масою тіла, ФП виявляли на 2,5 року раніше. А за наявності ЦД, ФП виникала в осіб, які були на 3 роки молодші порівняно $з$ контрольною групою ( $p=0,0067)$.

Індекс Кетле в групі ФП із коморбідними АГ і ЦД становив $(32,4 \pm 1,19)$ кг/м², тоді як в групі ідіо-

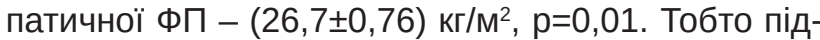
тверджуються дані літератури щодо впливу надмірної маси тіла на ініціацію ФП.

Вчені довели, що виникненню ФП передує розвиток дифузного фріброзу в передсердях, а він, у свою чергу, сприяє нерівномірним поширенням хвиль збудження унаслідок дисперсії рефрактерних періодів. При збільшенні маси передсердь, скороченні рефрактерного періоду й уповільненні внутрішньопередсердної провідності збільшується число «дочірніх» хвиль. Саме так фрормується механізм re-entry - хаотичне повторне порушення і множинне розповсюдження хвиль збудження, що сприяє виникненню ФП. Зважаючи на це, даному порушенню ритму може передувати будь-яка передсердна екстрасистола [12]. Однак за даними деяких джерел не тільки передсердні, а й шлуночкові ектрасистоли збільшують ризик виникнення ФП [3].

У нашій популяції хворих на АГ і ЦД суправентрикулярні екстрасистоли виявили у 21,6 \% пацієнтів, а шлуночкові екстрасистоли - в 32,4%. У пацієнтів, які мали в анамнезі епізоди ФП, екстрасистолію при синусовому ритмі (СР) на ЕКГ зафріксовано в кожної 2-3 особи ( $p=0,01)$.

Щодо причин виникнення і персистенції ФП, то АГ займає перше місце (близько 72 \% хворих із ФП страждають від АГ). Наявність ЦД 2 типу збільшує ризик розвитку ФП у 1,4-2,1 раза, натомість ЦД виявляється у 10-25 \% пацієнтів із попередньо діагностованою ФП. Разом 3 тим, поєднання ЦД 3 АГ підвищує ризик виникнення даної аритмії приблизно в 3 рази [2]. Хоча доведено, що діабетична кардіоміопатія (ДК) та діабетична кардіальна автономна нейропатія (ДКАН) сприяють появі ФП при ЦД, проте механізм, що лежить в основі цього взаємозв'язку до цього часу до кінця не з'ясований [11].

ФП виявляють близько у 4 \% поліклінічних хворих на ЦД, і у 15 \% стаціонарних пацієнтів [1]. Дослідження VALUE (2015) також показало, що АГ і ЦД мають синергічний ефект на розвиток ФП.

Дані літератури щодо частки ФП у хворих на АГ і ЦД досить неоднозначні, проте усі підтверджують вплив цієї коморбідності на частоту розвитку ФП.

Згідно 3 нашими дослідженнями ЦД спостерігався у 28,2 \% пацієнтів з ФП. Гіпертонічна хвороба (ГХ) була діагностована у $89 \%$ осіб із даною аритмією. Індекс коморбідності Чарльсона (відсоток 10-річного виживання) виявився вищим у групі ідіопатичної ФП - 82,3 \%, тоді як в групі з ФП, АГ і ЦД він становив лише 41,9 \% ( $p=0,0001)$. Глибина ураження органів і систем (CIRS) також була набагато вищою в групі ФП, АГ і ЦД - $(14,3 \pm 0,61)$ бала проти групи ідіопатичної ФП - $(8,9 \pm 0,43)$ бала $(p=0,0001)$.

При дослідженні впливу ЦД на розвиток ФП в експерименті виявили, що поява пароксизму ФП може бути пов'язана з коливаннями рівня глюкози, а не 3 гіперглікемією. Зниження порогу больової чутливості у хворих на ЦД не дозволяє їм вчасно зменшити фрізичне навантаження і призводить до посилення ішемії міокарда та виникнення порушень серцевого ритму [11].

Окремі дослідження оцінювали вираження серцебиття у пацієнтів з різними формами ФП, в результаті яких доведено, що у жінок симптоми ФП більш виражені та більша частота серцевих скорочень (чСС), ніж в чоловіків. Також відомо, що у пацієнтів молодшого віку частіше спостерігається пароксизмальна форма ФП і такі хворі суб'єктивно переносять аритмію суттєво гірше, ніж особи з постійною ФП. Результати 20-річного реєстру показали, що у пацієнтів з ЦД менш виражені або не відчутні симптоми серцебиття та нижчі показники варіабельності серцевого ритму при ФП [13]. Одним із тверджень, що могли пояснити такий френомен, вважають наявність нейропатії, яка призводить до зменшення больових відчуттів. Також доведено, що відсутність серцебиття у пацієнтів із ФП пов'язана з гіршим результатом незалежно від інших фракторів ризику та терапії. Проте механізми, що лежать в основі відсутності чи наявності патологічного серцебиття як симптому, вимагають майбутніх досліджень [11].

Подібні дані, які ми отримали при аналізі клінічної симптоматики, зокрема пацієнти з ЦД відчували серцебиття та перебої у роботі серця в 52,5\% випадків, тоді як в групі без ЦД - в 73,6 \% випадків $(p=0,004)$.

У групі обстежених хворих із ФП частота серцевих скорочень (ЧСС) була приблизно однаковою як в чоловіків, так і в жінок. Вираження симптомів у них також суттєво не відрізнялись. Проте симптоми значно частіше відчували в групах пароксизмальної та персистуючої фрорми ФП - в 94,5 \% випадків проти 67,7 \% в групі постійної фрорми (p=0,003). Хворі на АГ та ЦД часто не відчували симптомів аритмії, тому ФП у них мала прогресивний перебіг і частіше переходила у постійну форму.

Велика кількість епідеміологічних досліджень, які проводили серед хворих на гіпертонічну хворобу, довели, що в осіб, у яких згодом виник пароксизм ФП, середнє значення систолічного АТ було вище, ніж у пацієнтів без порушення ритму [15].

Багатоцентрове п'ятирічне дослідження LIFE (2005) також показало, що початкові величини САТ мають вагомий вплив на виникнення ФП. Дослі- 
джено, що при підвищенні САТ на кожні 10 мм рт. ст. ризик виникнення ФП збільшується на 6 \%. В результаті дослідження ADVANCE (2009) отримано такі ж дані. Доведено, що у пацієнтів з АГ та гіпертрофрією лівого шлуночка (ГЛШ), ризик виникнення ФП збільшується на $9 \%$ за кожен рік.

У нашому досліженні відносна товщина стінок (ВТС) в групі з ФП та АГ становила $(0,5 \pm 0,01)$ см, тоді як в групі СР - $(0,45 \pm 0,007)$ см $(p=0,003)$. Це свідчить про тривалий некорегований перебіг АГ у пацієнтів із діагностовано ФП.

У Фремінгемському дослідженні також доведено, що АГ і ЦД є незалежними предикторами розвитку ФП в одній і тій же віковій категорії. Досліджено, що підвищення САТ понад 160 мм. рт. ст. і ДАТ понад 95 мм. рт. ст. підвищувало ризик розвитку ФП в 1,5 раза у чоловіків і в 1,4 раза у жінок [10]. В дослідженнях LIFE i Val-HeFT (2000) відзначено, що у чоловіків з АГ на 56 і 53 \% відповідно частіше розвивалася ФП, ніж у жінок.

У результаті неодноразових досліджень доведено, що для обстеження пацієнтів з АГ та гіпертрофрією лівого шлуночка, крім загальноприйнятих методів, необхідно використовувати методику ХМ ЕКГ для уточнення кількості й характеру аритмій [4]. Однак чітких методологічних рекомендацій щодо використання даного методу немає.

Попередні результати нашого аналізу ХМ ЕКГ за участю 53 пацієнтів свідчать про недостатню інфрормативність 24-годинної реєстрації ЕКГ для виявлення прихованих аритмій.

У низці робіт звертають увагу на вплив компенсації ЦД на проаритмогенну активність міокарда. Встановлено, що ризик розвитку ФП в два рази більший у пацієнтів із рівнем глікозильованого гемоглобіну вище 9 \% порівняно з особами, у яких він був менше $9 \%$ [2].

У більшості обстежених пацієнтів із ФП та ЦД за даними визначення глікованого Нb рівень компенсації діабету виявився кращим, ніж в групі хворих без ФП, що з найбільшою вірогідністю пов'язано з більш ретельним спостереженням, лікуванням та в цілому кращим комплаєнсом коморбідних хворих.

Окрему проблему складає механізм ремоделювання серця як за рахунок АГ і ЦД, так і ФП. При АГ розвивається ГЛШ, яка сприяє дилатації лівого передсердя (ЛП), через що знижується його скоротлива фрункція. Далі підвищується тиск у лівому передсерді, відбувається його дилатація і фрорму-

СПИСОК ЛІТЕРАТУРИ

1. Александров А. А. Мерцательная аритмия: новый лик сахарного диабета в XXI веке / А. А. Александров, М. Н. Ядрихинская, С. С. Кухаренко // Сахарный диабет. - 2011. - № 1. - С. 53-59. ється фріброз. Відомо також, що при ЦД порушується реполяризація шлуночків серця, викликається неоднорідна деполяризація передсердь та уповільнюється проведення електричного імпульсу по передсердях. Це призводить до створення множинних ділянок re-entry, що є причиною фрормування ФП. Деякі роботи виявили, що підвищення індексу маси міокарда лівого шлуночка (ММ ЛШ) чи зниження фрракції викиду (ФВ) ЛШ впливає на виникнення пароксизму ФП у хворих на АГ та ЦД 2 типу [7].

У нашому дослідженні наявність ФП діагносту-

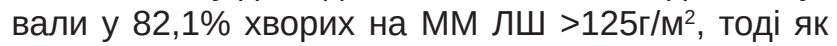

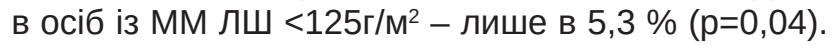
При зниженні ФВ <50 \% ФП виникала в 89,2 \% випадків, тоді як в групі з ФВ >50 \% ФП діагностувалась лише в $75 \%$ випадків ( $p=0,016)$.

Однак механізми розвитку серцевої недостатності на тлі АГ, ЦД чи ФП потребують подальшого визначення їх зв'язків. Не всі епідеміологічні дослідження дали однозначну позитивну відповідь на питання про незалежність причинно-наслідкового характеру взаємозв'язку між АГ, ЦД і виникненням чи погіршенням прогнозу ФП [7]. Наявність подібного взаємозв'язку за останні 10 років підтверджено у багатьох авторів [1], проте в ряді інших досліджень такі зв'язки не підтвердились [9]. Ймовірно, різниця могла бути пов'язана з різною методологією досліджень, зокрема різними характеристиками пароксизмів ФП, тривалістю ЦД, ступенем глікемічного контролю та ін. [1].

Вивчення різних аспектів виявлення ФП в умовах коморбідності 3 АГ і ЦД $є$ аргументованим. Нез'ясованість низки епідеміологічних, патогенетичних та клінічних аспектів проаритмогенезу у хворих на АГ і ЦД та перебіг у них ФП вимагають додаткового вивчення.

\section{ВИСНОВКИ}

ФП $€$ досить частим клінічним синдромом, особливо в умовах коморбідності. На даний час розповсюдження АГ в поєднанні з ЦД є значним та беззаперечно пов'язаними 3 виникненням інциденту розвитку ФП. При цьому вони разом мають безпосередній вплив як на перебіг основної патології, так і на перебіг аритмічного синдрому. Тому особливої актуальності набуває подальше ретельне вивчення проблеми виникнення і розвитку ФП в умовах коморбідних АГ і ЦД.

2. Артериальная гипертензия, сахарный диабет 2 типа и фиибилляция предсердий как самостоятельная медицинская проблема / А. В. Барсуков, Т. С. Свеклина, М. С. Таланцева, С. Б. Шустов // Артериальная гипертензия. - 2011. - Т. 17, № 2. - С. 108-114.
$4(6), 2020$ 
3. Бевзюк Л. В. Аналіз добової динаміки артеріального тиску в пацієнтів похилого віку з артеріальною гіпертензією та фрібриляцією передсердь / Л. В. Бевзюк, І. В. Мудрук // Кардиология: от науки к практике. - 2017. - № 2. - С. 19-28.

4. Еременко Е. Ю. Гипертоническое ремоделирование миокарда как фрактор риска развития фрибрилляции предсердий у пациентов с артериальной гипертензией I Е. Ю. Еременко, Е.А.Егорова, Л.А.Соколова // Вестник аритмологии. - 2011. - № 64. - С. 38-43.

5. Соколова Ю. А. Значення змін геометричної моделі серця на виникнення аритмій у хворих з коморбідним перебігом артеріальної гіпертензії та цукрового діабету 2 типу / Ю. А. Соколова, О. М. Біловол, І. А. Ільченко // Молодий вчений. - 2017. - № 9 - С. 67-69.

6. Фуштей И. М. Анализ вариабельности сердечного ритма у больных с персистирующей формой фрибрилляции предсердий на фоне артериальной гипертензии / И. М. Фуштей, А. В. Соловьев, Е. В. Сидь // Запорожский медицинский журнал. - 2014. - № 1 (82). - С. 64-65.

7. Шоріков $Є$. І. Предиктори ризику пароксизмів фрібриляції передсердь у хворих на артеріальну гіпертензію та цукровий діабет 2 типу: результати тривалого спостереження / Є. І. Шоріков // Науковий вісник Ужгородського університету. Сер. «Медицина». - 2013. - № 1. - С. 60-65.

8. The clinical profile and pathophysiology of atrial fibrillation: relationships among clinical features, epidemiology, and mechanisms / J. Andrade, P. Khairy, D. Dobrev, S. Nattel // Circ. Res. - 2014. - Vol. 114. - P. 1453-1468.

\section{REFERENCES}

1. Aleksandrov AA, Yadrykhynska MN, Kukharenko SS. Atrial fibrillation: a new facet of diabetes mellitus in the XXI century. Diabetes mellitus. 2011;(1): 53-9. Available from: https://doi.org/10.14341/2072-0351-6250.

2. Barsukov AV, Sveklyna TS, Talantseva MS., Shustov SB. Hypertension, type 2 diabetes mellitus, and atrial fibrillation as a separate medical problem. Arterial hypertension. 2011;17(2): 108-14. Available from: https://doi. org/10.18705/1607-419X-2011--2-

3. Bevzyuk LV, Mudruk IV. 24-h blood pressure monitoring in elderly hypertensive patients with atrial fibrillation. Cardiology: from science to practice. 2017;(2): 19-28.

4. Eremenko EY, Ehorova EA, Sokolova LA. Hypertensive myocardial remodeling as a risk factor of atrial fibrillation in patients with arterial hypertension. Journal of Arrhythmology. 2011;(64): 38-43

5. Sokolova YA, Bilovol OM, Ilchenko IA. The influence of myocardium remodeling on the emergence of arrhythmias in patients with hypertension and diabetes mellitus. Young Scientist. 2017;(9): 67-9.

6. Fushtei IM, Solovyev AV, Sid EV. [Analysis of heart rate variability in patients with persistent atrial fibrillation associated with arterial hypertension]. Zapor med zhurn. 2014;1(82): 64-5. Available from: https://doi. org/10.14739/2310-1210.2014.1.23769. Russian.

7. Shorikov El. [The predictors of paroxysmal atrial fibrillation in patients with arterial hypertension and concomitant diabetes mellitus of type 2: results of long-term investigation]. Nauk. visn Uzhhorod univer. Ser «Med». 2013;(1): 60-5. Ukrainian.
9. Atrial fibrillation in the Malmö Diet and Cancer study: a study of occurrence, risk factors and diagnostic validity I J. G. Smith, P. G. Platonov, B. Hedblad [et al.] // Eur. Journal Epidemiol. - 2010. - No. 25. - P. 95-102.

10. Risk factor management in atrial fibrillation / A. Brandes, B. O. Nguyen, M. Rienstra, Van I. Gelder // Arrhythmia \& Electrophysiology Review. - 2018. - Vol. 7 (2). - P. 118- 127.

11. Role of diabetes in heart rhythm disorders // B. Koektuerk, M. Aksoy, M. Horlitz [et al.] // World Journal Diabetes. - 2016. - Vol. 7 (3). - P. 45-49.

12. Nattel S. Atrial remodeling and atrial fibrillation: recent advances and translational perspectives / S. Nattel, M. Harada // Journal of the American College of Cardiology. - 2014. - Vol. 63 (22). - P. 2335-2345.

13. The prognostic implications of lack of palpitations in patients hospitalised with atrial fibrillation: observations from a 20-year registry / A. M. Salam, B. J. Gersh, H. A. Al.-Binali [et al.] // International Journal Clin. Pract. 2014. - Vol. 68. - P. 122-129.

14. Pathogenetic mechanisms and signs of cardiovascular disorders in type 2 diabetes mellitus / L. V. Shkala, G. I. Mishanich, O. V. Shkala [et al.] // Международный эндокринологический журнал. - 2018. - Т. 14. - № 3. С. 235-239.

15. Prevalence of arterial hypertension in patients with atrial fibrillation undergoing ablation. A prospective, cohort study / F. M. Szymanski, K. J. Filipiak, A. E. Platek [et al.] // Journal of Hypertension. - 2015. - Vol. 19 (3). - P. 135-139.

8. Andrade J, Khairy P, Dobrev D, Nattel S. The clinical profile and pathophysiology of atrial fibrillation: relationships among clinical features, epidemiology, and mechanisms. Circ Res. 2014;114: 1453-68. Available from: https://doi: 10.1161/CIRCRESAHA.114.303211.

9. Smith JG, Platonov PG, Hedblad B, Engström G, Melander $O$. Atrial fibrillation in the Malmö diet and cancer study: A study of occurrence, risk factors and diagnostic validity. Eur J Epidemiol. 2010;(25): 95-102. Available from: https://doi:10.1007/s10654-009-9404-1.

10. Brandes A, Smit MD, Nguyen BO, Rienstra M, Van Gelder I. Risk factor management in atrial fibrillation. Arrhythmia \& Electrophysiology Review. 2018;7(2): 118-27. Available from: https://doi: 10.1007/s10654-009-9404-1.

11. Koektuerk B, Aksoy M, Horlitz M, Bozdag-Turan I, Turan RG. Role of diabetes in heart rhythm disorders. World J. Diabetes. 2016;7(3): 45-9. Available from: https://doi: 10.4239/wjd.v7.i3.45

12. Nattel S., Harada M. Atrial remodeling and atrial fibrillation: recent advances and translational perspectives. J Am Coll Cardiol. 2014;63(22): 2335-45. Available from: https://doi: 10.1016/j.jacc.2014.02.555.

13. Salam AM, Gersh BJ, AlBinali HA, Singh R, Asaad $\mathrm{N}, \mathrm{Al}-\mathrm{Q} a h t a n \mathrm{~A}$, et al. The prognostic implications of lack of palpitations in patients hospitalised with atrial fibrillation: observations from a 20-year registry. International J Clin Pract. 2014;68: 122-9. Available from: https://doi:10.1111/ ijcp.12230.

14. Shkala LV, Mishanich GI, Shkala OV, Cherpak OV, Karapetyan EA, Volkovskaya TG. Pathogenetic mecha- 
nisms and signs of cardiovascular disorders in type 2 diabetes mellitus. Международный эндокринологический журнал. 2018;14(3): 235-9. Available from: https://doi. org/10.22141/2224-0721.14.3.2018.136418.
15. Szymanski FM, Filipiak KJ, Platek AE, Kotkowski M, Opolski G. Prevalence of arterial hypertension in patients with atrial fibrillation undergoing ablation. A prospective, cohort study. J of Hypertension. 2015;33;65. Available from: https://doi: 10.1097/01.hjh.0000467523.89875.59. 